\title{
Pedobacter terrae sp. nov., isolated from soil
}

\author{
Jung-Hoon Yoon, So-Jung Kang and Tae-Kwang Oh
}

Correspondence

Jung-Hoon Yoon

jhyoon@kribb.re.kr

\author{
Korea Research Institute of Bioscience and Biotechnology (KRIBB), PO Box 115, Yusong, \\ Taejon, Korea
}

\begin{abstract}
A Gram-negative, non-motile, rod-shaped bacterial strain, DS- $57^{\top}$, was isolated from soil from Dokdo, Korea, and its taxonomic position was investigated using a polyphasic approach. It grew optimally at $25{ }^{\circ} \mathrm{C}$ and in trypticase soy broth without $\mathrm{NaCl}$ and trypticase soy broth with $0.5 \%$ $\mathrm{NaCl}$. Strain DS $-57^{\top}$ contained MK-7 as the predominant menaquinone and iso- $\mathrm{C}_{15: 0}$, $\mathrm{C}_{16: 1} \omega 7 \mathrm{c}$ and/or iso- $\mathrm{C}_{15: 0} 2-\mathrm{OH}$ and iso- $\mathrm{C}_{17: 0} 3-\mathrm{OH}$ as the major fatty acids. The DNA G+C content was 39.7 mol\%. Phylogenetic analyses based on 16S rRNA gene sequences revealed that strain DS $-57^{\top}$ was most closely related to the genus Pedobacter of the family

Sphingobacteriaceae, clustering coherently with Pedobacter suwonensis, Pedobacter roseus and Pedobacter sandarakinus. Strain DS $-57^{\top}$ exhibited $16 \mathrm{~S}$ rRNA gene sequence similarity values of $99.2,97.9$ and $97.2 \%$ with respect to the type strains of $P$. suwonensis, $P$. roseus and $P$. sandarakinus, respectively, and values less than $95.6 \%$ with respect to the type strains of other Pedobacter species. Strain DS-57 $7^{\top}$ exhibited levels of DNA-DNA relatedness of 45,17 and $15 \%$ with respect to the type strains of $P$. suwonensis, $P$. roseus and $P$. sandarakinus, respectively. Differential phenotypic properties, together with the phylogenetic distinctiveness and the DNA-DNA relatedness data, were sufficient to allow the classification of strain $D S-57^{\top}$ as a species that is separate from recognized Pedobacter species. On the basis of phenotypic properties and phylogenetic distinctiveness, therefore, strain DS- $57^{\top}$ represents a novel species of the genus Pedobacter, for which the name Pedobacter terrae sp. nov. is proposed. The type strain is DS $-57^{\top}\left(=\right.$ KCTC $12762^{\top}=$ DSM $\left.17933^{\top}\right)$.
\end{abstract}

The genus Pedobacter was proposed by Steyn et al. (1998) with the reclassification of two Sphingobacterium species and the description of two novel species. At the time of writing, the genus comprises 12 recognized species: Pedobacter heparinus, Pedobacter piscium, Pedobacter africanus and Pedobacter saltans (Steyn et al., 1998), Pedobacter cryoconitis (Margesin et al., 2003), Pedobacter himalayensis (Shivaji et al., 2005), Pedobacter caeni (Vanparys et al., 2005), Pedobacter sandarakinus (Yoon et al., 2006), Pedobacter roseus (Hwang et al., 2006), Pedobacter aquatilis (Gallego et al., 2006), Pedobacter ginsengisoli (Ten et al., 2006) and Pedobacter suwonensis (Kwon et al., 2007). The genus Pedobacter is characterized chemotaxonomically by having $\mathrm{MK}-7$ as the predominant menaquinone and iso$\mathrm{C}_{15: 0}$ and iso- $\mathrm{C}_{15: 0} 2-\mathrm{OH}$ and/or $\mathrm{C}_{16: 1} \omega 7 c$ as the major fatty acids (Steyn et al., 1998; Kwon et al., 2007). Phylogenetic analyses based on 16S rRNA gene sequences have shown that the genus Pedobacter falls within the phylum Bacteroidetes (the Cytophaga-FlavobacteriumBacteroides group) (Bernardet et al., 2002; Kwon et al.,

The GenBank/EMBL/DDBJ accession number for the 16S rRNA gene sequence of strain DS-57 $57^{\top}$ is DO889723.

The cellular fatty acid content of strain DS- $57^{\top}$ and phylogenetically related Pedobacter species is presented in a supplementary table available with the online version of this paper.
2007). Here, we report on the taxonomic characterization of a Pedobacter-like bacterial strain, DS $-57^{\mathrm{T}}$, which was isolated from a soil sample from Dokdo $\left(37^{\circ} 14^{\prime} 12^{\prime \prime} \mathrm{N} 131^{\circ}\right.$ $\left.52^{\prime} 07^{\prime \prime} \mathrm{E}\right)$, an island of Korea.

Strain $\mathrm{DS}-57^{\mathrm{T}}$ was isolated using the standard dilution plating technique on $2 \times$ diluted nutrient agar (Difco) at $25{ }^{\circ} \mathrm{C}$. The type strains of three Pedobacter species were used as reference strains for DNA-DNA hybridization and phenotypic characterization: $P$. roseus KACC $11594^{\mathrm{T}}$ and $P$. suwonensis KACC $11317^{\mathrm{T}}$ (obtained from the Korean Agricultural Culture Collection, Suwon, Korea) and $P$. sandarakinus DS- $27^{\mathrm{T}}$ (Yoon et al., 2006). The morphological, physiological and biochemical characteristics of strain DS $-57^{\mathrm{T}}$ were investigated using routine cultivation on trypticase soy agar (TSA; Difco) at $25{ }^{\circ} \mathrm{C}$. The cell morphology was examined by light microscopy (E600; Nikon) and transmission electron microscopy. The presence of flagella was determined by transmission electron microscopy using cells from exponentially growing cultures. For the transmission electron microscopic observations, the cells were negatively stained with $1 \%(\mathrm{w} / \mathrm{v})$ phosphotungstic acid and the grids were examined after air-drying with a Philips CM-20 transmission electron microscope. Gliding motility was determined as described by Bowman (2000) using quarter-strength trypticase soy 
broth (TSB; Difco) solidified with $1 \%(\mathrm{w} / \mathrm{v})$ agarose and R2A agar (Difco). The Gram reaction was determined using the bioMérieux Gram-stain kit according to the manufacturer's instructions. Growth at various temperatures $\left(4-40{ }^{\circ} \mathrm{C}\right)$ was measured on TSA. Growth in the absence of $\mathrm{NaCl}$ and at various $\mathrm{NaCl}$ concentrations $(0.5$ and $1.0-5.0 \%, \mathrm{w} / \mathrm{v}$, using increments of $1.0 \%$ ) was investigated in TSB prepared according to the formula of the Difco medium except that $\mathrm{NaCl}$ was excluded. The $\mathrm{pH}$ range for growth was determined in nutrient broth (Difco) that had been adjusted to various $\mathrm{pH}$ values ( $\mathrm{pH} 4.5-10.5$, using increments of $0.5 \mathrm{pH}$ units), prior to sterilization, by the addition of $\mathrm{HCl}$ or $\mathrm{Na}_{2} \mathrm{CO}_{3}$. Growth at $\mathrm{pH} 4.5,5.0$ and 5.5 was investigated in nutrient broth adjusted to each value using a citrate/phosphate buffer $(0.1 \mathrm{M}$ citrate/ $0.2 \mathrm{M}$ $\mathrm{Na}_{2} \mathrm{HPO}_{4}$ ) (Breznak \& Costilow, 1994). Growth under anaerobic conditions was determined after incubation in an anaerobic chamber on TSA and on TSA supplemented with nitrate, both of which had been prepared anaerobically using nitrogen. Catalase and oxidase activities and hydrolysis of casein, gelatin, hypoxanthine, starch, Tweens 20, 40, 60 and 80, tyrosine, urea and xanthine were determined as described by Cowan \& Steel (1965). DNase activity was examined by using DNase test agar with methyl green (Difco). Hydrolysis of aesculin and nitrate reduction were studied as described previously (Lanyi, 1987). The presence of flexirubin-type pigments was investigated as described by Reichenbach (1992). Susceptibility to antibiotics was tested on TSA plates, using antibiotic discs containing the following concentrations ( $\mu \mathrm{g}$, unless indicated otherwise): polymyxin $\mathrm{B}, 100 \mathrm{U}$; streptomycin, 50; penicillin G, $20 \mathrm{U}$; chloramphenicol, 100; ampicillin, 10; cephalothin, 30; gentamicin, 30; novobiocin, 5; tetracycline, 30; kanamycin, 30; lincomycin, 15; oleandomycin, 15; neomycin, 30; carbenicillin, 100 . Assimilation of various substrates, enzyme activities and other physiological and biochemical properties were tested by using the API 20E, API 20NE, API 50 CHB and API ZYM systems (bioMérieux). The cells were suspended in AUX medium (bioMérieux), according to the manufacturer's instructions, for inoculation into the API $50 \mathrm{CH}$ system.

Cell biomass for DNA extraction and for isoprenoid quinone analysis was obtained from cultivation in TSB at $25{ }^{\circ} \mathrm{C}$. Chromosomal DNA was isolated and purified according to the method described by Yoon et al. (1996), except that RNase T1 was used in combination with RNase A to minimize contamination with RNA. The $16 \mathrm{~S}$ rRNA gene was amplified by using a PCR with two universal primers, as described previously (Yoon et al., 1998). The sequencing of the amplified 16S rRNA gene and the phylogenetic analysis were performed as described by Yoon et al. (2003). Isoprenoid quinones were extracted according to the method of Komagata \& Suzuki (1987) and analysed using reversed-phase HPLC and a YMC ODS-A $(250 \times 4.6 \mathrm{~mm})$ column. For fatty acid methyl ester analysis, cell mass of strain DS- $57^{\mathrm{T}}$ was harvested from
TSA plates after incubation for 3 days at $25{ }^{\circ} \mathrm{C}$. The fatty acid methyl esters were extracted and prepared according to the standard protocol of the MIDI/Hewlett Packard Microbial Identification System (Sasser, 1990). The DNA $\mathrm{G}+\mathrm{C}$ content was determined using the method of Tamaoka \& Komagata (1984), with the modification that DNA was hydrolysed and the resultant nucleotides were analysed by reversed-phase HPLC.

Morphological, cultural, physiological and biochemical characteristics of strain DS $-57^{\mathrm{T}}$ are given in the species description (see later) or are shown in Table 1. The almostcomplete 16S rRNA gene sequence of strain DS- $57^{\mathrm{T}}$ determined in this study comprised $1477 \mathrm{nt}$ (approx. $96 \%$ of the Escherichia coli $16 \mathrm{~S}$ rRNA gene sequence). The $16 \mathrm{~S}$ rRNA gene sequence analyses showed that strain DS$57^{\mathrm{T}}$ was phylogenetically most closely related to the genus Pedobacter of the family Sphingobacteriaceae (Fig. 1). In the neighbour-joining phylogenetic tree based on 16S rRNA gene sequences, strain DS- $57^{\mathrm{T}}$ fell within the cluster comprising the Pedobacter species, in particular forming a coherent cluster with $P$. suwonensis, $P$. roseus, $P$. sandarakinus and $P$. aquatilis (Fig. 1). Strain DS-57 $7^{\mathrm{T}}$ exhibited $16 \mathrm{~S}$ rRNA gene sequence similarity values ranging from $93.8 \%$ (P. himalayensis) to $99.2 \%$ (P. suwonensis) with respect to the type strains of Pedobacter species (with the exception of $P$. saltans); the values were below $91.8 \%$ for the other species used in the phylogenetic analysis.

Strain DS- $57^{\mathrm{T}}$ contained MK-7 (at a peak area ratio of approx. $87 \%$ ) as the predominant isoprenoid quinone; a significant amount of MK-6 (approx. 10\%) was also detected. The fatty acids constituting $>0.5 \%$ of the total fatty acid content for strain DS- $57^{\mathrm{T}}$ were as follows: branched fatty acids iso- $\mathrm{C}_{15: 0}(28.3 \%)$, iso- $\mathrm{C}_{17: 1} \omega 9 c$ $(6.1 \%)$ and anteiso- $\mathrm{C}_{15: 0}(0.8 \%)$; summed feature 3 (comprising $\mathrm{C}_{16: 1} \omega 7 c$ and/or iso- $\mathrm{C}_{15: 0} 2-\mathrm{OH} ; 27.7 \%$ ) and summed feature 4 (comprising iso- $\mathrm{C}_{17: 1}$ and/or anteiso- $\mathrm{C}_{17: 1} ; 1.2 \%$ ); hydroxyl fatty acids iso- $\mathrm{C}_{17: 0} 3-\mathrm{OH}$ $(20.4 \%)$, iso- $\mathrm{C}_{15: 0} 3-\mathrm{OH}(3.5 \%), \mathrm{C}_{16: 0} 3-\mathrm{OH}(1.6 \%)$ and iso- $\mathrm{C}_{16: 0} 3-\mathrm{OH}(0.6 \%)$; straight-chain fatty acid $\mathrm{C}_{16: 0}$ (1.9\%); unsaturated fatty acids $\mathrm{C}_{16: 1} \omega 5 c(1.7 \%)$ and $\mathrm{C}_{18: 1} \omega 5 c(0.9 \%)$; and an unknown fatty acid (equivalent chain length, 16.582) $(1.2 \%)$. This fatty acid profile was similar to those of Pedobacter species, although there were differences in the proportions of some fatty acids, perhaps because of differences in cultivation conditions (Shivaji et al., 2005; Vanparys et al., 2005; Yoon et al., 2006; Hwang et al., 2006; Kwon et al., 2007) (see Supplementary Table $\mathrm{S} 1$, available with the online version of this paper). The DNA G + C content of strain DS $-57^{\mathrm{T}}$ was $39.7 \mathrm{~mol} \%$. These chemotaxonomic properties were in agreement with the monothetic phylogenetic classification of strain DS- $57^{\mathrm{T}}$ as a member of the genus Pedobacter (Steyn et al., 1998; Margesin et al., 2003; Shivaji et al., 2005; Vanparys et al., 2005; Yoon et al., 2006; Hwang et al., 2006).

The mean values for DNA-DNA relatedness between strain DS- $57^{\mathrm{T}}$ and the type strains of three phylogenetically 
Table 1. Differential characteristics of strain $D S-57^{\top}$ and some phylogenetically related Pedobacter species

Taxa: 1, DS-57 ${ }^{\mathrm{T}}$; 2, P. suwonensis, data from Kwon et al. (2007) and this study; 3, P. roseus, data from Hwang et al. (2006) and this study; 4, P. sandarakinus, data from Yoon et al. (2006); 5, P. aquatilis, data from Gallego et al. (2006). All species are positive for the following: catalase (data for P. suwonensis and P. roseus from this study), oxidase (data for $P$. suwonensis and $P$. roseus from this study), aesculin hydrolysis (data for P. suwonensis and P. roseus from this study), esterase (C4), esterase lipase (C8), acid phosphatase, alkaline phosphatase, leucine arylamidase, naphthol-AS-BI-phosphohydrolase, $\beta$-galactosidase, $\alpha$-glucosidase, $\beta$-glucosidase and $N$-acetyl- $\beta$-glucosaminidase; assimilation of D-galactose, D-glucose, D-mannose, $\mathrm{N}$-acetylglucosamine, amygdalin, salicin, D-cellobiose, maltose, lactose, melibiose, sucrose, trehalose, starch and gentiobiose; and susceptibility to chloramphenicol and tetracycline. All species are negative for the following: motility; Gram stain; sporulation; urease (data for P. suwonensis and P. roseus from this study), arginine dihydrolase (data for $P$. suwonensis and $P$. roseus from this study), indole and $\mathrm{H}_{2} \mathrm{~S}$ production (data for $P$. suwonensis and P. roseus from this study), nitrate reduction (data for P. suwonensis and $P$. roseus from this study), lipase (C14), $\alpha$-chymotrypsin and $\beta$-glucuronidase; assimilation of glycerol, erythritol, D-arabinose, L-xylose, ribose, adonitol, sorbose, dulcitol, inositol, mannitol, sorbitol, xylitol, D-lyxose, D-tagatose, D-fucose, L-fucose, D-arabitol, L-arabitol, gluconate, 2-ketogluconate, caprate, adipate, malate, citrate and phenylacetate; and susceptibility to ampicillin, gentamicin, kanamycin and penicillin. + , Positive reaction; -, negative reaction; w, weakly positive reaction; ND, not determined.

\begin{tabular}{|c|c|c|c|c|c|}
\hline Characteristic & 1 & 2 & 3 & 4 & 5 \\
\hline Colony colour & Orange & Pinkish yellow & Pink & Orange & Pink \\
\hline Maximum growth temperature $\left({ }^{\circ} \mathrm{C}\right)$ & 35 & 37 & 33 & 33 & 30 \\
\hline Growth on MacConkey medium & - & - & + & - & - \\
\hline Cell shape & Rods & Rods & Short rods & Rods/long rods & Rods \\
\hline \multicolumn{6}{|l|}{ Hydrolysis of ${ }^{\star}$ : } \\
\hline Casein & + & + & + & - & - \\
\hline Gelatin & + & + & + & - & - \\
\hline Starch & + & + & + & - & + \\
\hline \multicolumn{6}{|l|}{ Enzyme activities (API ZYM)* } \\
\hline Valine arylamidase & + & - & - & - & + \\
\hline Cystine arylamidase & - & - & - & $\mathrm{w}$ & + \\
\hline Trypsin & - & - & $\mathrm{W}$ & - & + \\
\hline$\alpha$-Galactosidase & - & - & - & - & - \\
\hline$\alpha$-Mannosidase & - & - & - & - & + \\
\hline$\alpha$-Fucosidase & - & $\mathrm{w}$ & $\mathrm{w}$ & - & - \\
\hline \multicolumn{6}{|l|}{ Assimilation of: ${ }^{*}$} \\
\hline L-Arabinose & + & + & + & - & + \\
\hline D-Xylose & + & + & + & - & - \\
\hline Methyl $\beta$-D-xyloside & + & + & - & - & - \\
\hline D-Fructose & + & + & + & - & + \\
\hline L-Rhamnose & - & + & + & - & + \\
\hline Methyl $\alpha$-D-mannoside & + & + & + & $\mathrm{w}$ & + \\
\hline Methyl $\alpha$-D-glucoside & + & + & + & w & + \\
\hline Arbutin & + & + & + & - & + \\
\hline Inulin & + & - & - & - & - \\
\hline D-Melezitose & - & + & - & - & + \\
\hline D-Raffinose & + & + & + & - & + \\
\hline Glycogen & - & + & + & + & - \\
\hline Turanose & + & + & + & - & + \\
\hline 5-Ketogluconate & - & - & - & + & - \\
\hline \multicolumn{6}{|l|}{ Susceptibility to:* } \\
\hline Novobiocin & - & + & + & + & ND \\
\hline Streptomycin & - & $\mathrm{w}$ & + & - & - \\
\hline DNA G $+C$ content $(\mathrm{mol} \%)$ & 39.7 & 44.2 & 41.3 & 39.7 & 38 \\
\hline
\end{tabular}

${ }^{*}$ Data for P. suwonensis and P. roseus from this study. 


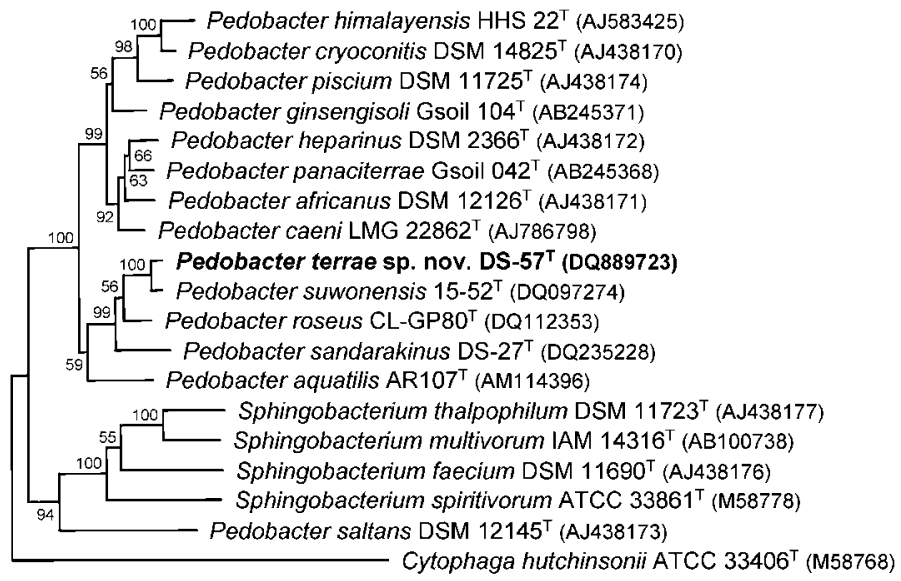

$\underline{0.01}$
Fig. 1. Neighbour-joining phylogenetic tree, based on 16S rRNA gene sequences, showing the positions of strain DS- $57^{\top}$ and some related taxa. Bootstrap percentages (based on 1000 replications) are shown at the nodes (if $\geqslant 50 \%$ ). Cytophaga hutchinsonii ATCC $33406^{\top}$ was used as an outgroup. Bar, 0.01 substitutions per nucleotide position. related Pedobacter species, namely $P$. suwonensis $15-52^{\mathrm{T}}, P$. roseus $\mathrm{CL}-\mathrm{GP} 80^{\mathrm{T}}$ and $P$. sandarakinus $\mathrm{DS}-27^{\mathrm{T}}$, which showed 16S rRNA gene sequence similarity values of $>97.0 \%$ with respect to strain DS- $57^{\mathrm{T}}$, were $15-45 \%$ when their DNAs were used individually as labelled DNA probes. Strain DS $-57^{\mathrm{T}}$ was distinguishable from some phylogenetically related Pedobacter species through differences in several phenotypic characteristics, as listed in Table 1 . The phylogenetic distinctiveness of $\mathrm{DS}-57^{\mathrm{T}}$, the differential phenotypic properties and the DNA-DNA relatedness data were sufficient to demonstrate that this strain is distinct from recognized Pedobacter species (Wayne et al., 1987; Stackebrandt \& Goebel, 1994). Therefore, on the basis of the data presented, strain DS- $57^{\mathrm{T}}$ represents a novel member of the genus Pedobacter, for which the name Pedobacter terrae sp. nov. is proposed.

\section{Description of Pedobacter terrae sp. nov.}

Pedobacter terrae (ter'rae. L. gen. n. terrae of the earth).

Cells are Gram-negative, non-spore-forming, non-flagellated rods $(0.3-0.5 \times 0.8-3.5 \mu \mathrm{m})$. Colonies on TSA are circular, convex, smooth, glistening, orange-coloured and $1.0-2.0 \mathrm{~mm}$ in diameter after incubation for 3 days at $25{ }^{\circ} \mathrm{C}$. Optimal growth occurs at $25{ }^{\circ} \mathrm{C}$; growth occurs at 4 and $35{ }^{\circ} \mathrm{C}$, but not at $36{ }^{\circ} \mathrm{C}$. Optimal pH for growth is 6.5-7.5; growth occurs at $\mathrm{pH} 5.5$ and 9.0, but not at $\mathrm{pH} 5.0$ or 9.5. Optimal growth occurs in TSB without $\mathrm{NaCl}$ and TSB with $0.5 \% \mathrm{NaCl}$; growth does not occur in the presence of greater than $3 \%(w / v) ~ N a C l$. Growth does not occur under anaerobic conditions on TSA or on TSA supplemented with nitrate. DNase-negative. Tweens 20, 40, 60 and 80 are hydrolysed, but hypoxanthine, xanthine and L-tyrosine are not. Lysine decarboxylase, ornithine decarboxylase and tryptophan deaminase are absent. Flexirubin-type pigments are absent. Susceptible to lincomycin and oleandomycin, but not to polymyxin B, cephalothin, carbenicillin or neomycin. The predominant menaquinone is MK-7. The major fatty acids (constituting
$>10 \%$ of total fatty acids) are iso- $\mathrm{C}_{15: 0}, \mathrm{C}_{16: 1} \omega 7 c$ and/or iso- $\mathrm{C}_{15: 0} 2-\mathrm{OH}$ and iso- $\mathrm{C}_{17: 0} 3-\mathrm{OH}$. The DNA $\mathrm{G}+\mathrm{C}$ content is $39.7 \mathrm{~mol} \%$ (HPLC). Other phenotypic properties are shown in Table 1.

The type strain, DS $-57^{\mathrm{T}}\left(=\right.$ KCTC $\left.12762^{\mathrm{T}}=\mathrm{DSM} 17933^{\mathrm{T}}\right)$, was isolated from soil.

\section{Acknowledgements}

This work was supported by the 21C Frontier Program of Microbial Genomics and Applications (grant MG05-0401-2-0) from the Ministry of Science and Technology (MOST) of the Republic of Korea.

\section{References}

Bernardet, J.-F., Nakagawa, Y. \& Holmes, B. (2002). Proposed minimal standards for describing new taxa of the family Flavobacteriaceae and emended description of the family. Int J Syst Evol Microbiol 52, 1049-1070.

Bowman, J. P. (2000). Description of Cellulophaga algicola sp. nov., isolated from the surfaces of Antarctic algae, and reclassification of Cytophaga uliginosa (ZoBell and Upham 1944) Reichenbach 1989 as Cellulophaga uliginosa comb. nov. Int J Syst Evol Microbiol 50, 1861-1868.

Breznak, J. A. \& Costilow, R. N. (1994). Physicochemical factors in growth. In Methods for General and Molecular Bacteriology, pp. 137154. Edited by P. Gerhardt, R. G. E. Murray, W. A. Wood \& N. R. Krieg. Washington, DC: American Society for Microbiology.

Cowan, S. T. \& Steel, K. J. (1965). Manual for the Identification of Medical Bacteria. London: Cambridge University Press.

Gallego, V., García, M. T. \& Ventosa, A. (2006). Pedobacter aquatilis sp. nov., isolated from drinking water, and emended description of the genus Pedobacter. Int J Syst Evol Microbiol 56, 1853-1858.

Hwang, C. Y., Choi, D. H. \& Cho, B. C. (2006). Pedobacter roseus sp. nov., isolated from a hypertrophic pond, and emended description of the genus Pedobacter. Int J Syst Evol Microbiol 56, 1831-1836.

Komagata, K. \& Suzuki, K. (1987). Lipid and cell-wall analysis in bacterial systematics. Methods Microbiol 19, 161-207.

Kwon, S.-W., Kim, B. Y., Lee, K.-H., Jang, K.-Y., Seok, S.-J., Kwon, J.-S., Kim, W.-G. \& Weon, H. Y. (2007). Pedobacter suwonensis sp. nov., 
isolated from the rhizosphere of Chinese cabbage (Brassica campestris). Int J Syst Evol Microbiol 57, 480-484.

Lanyi, B. (1987). Classical and rapid identification methods for medically important bacteria. Methods Microbiol 19, 1-67.

Margesin, R., Spröer, C., Schumann, P. \& Schinner, F. (2003). Pedobacter cryoconitis sp. nov., a facultative psychrophile from alpine glacier cryoconite. Int J Syst Evol Microbiol 53, 1291-1296.

Reichenbach, H. (1992). The order Cytophagales. In The Prokaryotes, 2nd edn, vol. 4, pp. 3631-3675. Edited by A. Balows, H. G. Trüper, M. Dworkin, W. Harder \& K. H. Schleifer. New York: Springer.

Sasser, M. (1990). Identification of bacteria by gas chromatography of cellular fatty acids, MIDI Technical Note 101. Newark, DE: MIDI.

Shivaji, S., Chaturvedi, P., Reddy, G. S. N. \& Suresh, K. (2005). Pedobacter himalayensis sp. nov., from the Hamta glacier located in the Himalayan mountain ranges of India. Int J Syst Evol Microbiol 55, 1083-1088.

Stackebrandt, E. \& Goebel, B. M. (1994). Taxonomic note: a place for DNA-DNA reassociation and 16S rRNA sequence analysis in the present species definition in bacteriology. Int J Syst Bacteriol 44, 846-849.

Steyn, P. L., Segers, P., Vancanneyt, M., Sandra, P., Kersters, K. \& Joubert, J. J. (1998). Classification of heparinolytic bacteria into a new genus, Pedobacter, comprising four species: Pedobacter heparinus comb. nov., Pedobacter piscium comb. nov., Pedobacter africanus sp. nov. and Pedobacter saltans sp. nov. Proposal of the family Sphingobacteriaceae fam. nov. Int J Syst Bacteriol 48, 165-177.
Tamaoka, J. \& Komagata, K. (1984). Determination of DNA base composition by reversed-phase high-performance liquid chromatography. FEMS Microbiol Lett 25, 125-128.

Ten, L. N., Liu, Q.-M., Im, W.-T., Lee, M., Yang, D.-C. \& Lee, S.-T. (2006). Pedobacter ginsengisoli sp. nov., a novel DNase-producing bacterium isolated from soil of a ginseng field in South Korea. Int $J$ Syst Evol Microbiol 56, 2565-2570.

Vanparys, B., Heylen, K., Lebbe, L. \& De Vos, P. (2005). Pedobacter caeni sp. nov., a novel species isolated from a nitrifying inoculum. Int J Syst Evol Microbiol 55, 1315-1318.

Wayne, L. G., Brenner, D. J., Colwell, R. R., Grimont, P. A. D., Kandler, O., Krichevsky, M. I., Moore, L. H., Moore, W. E. C., Murray, R. G. E. \& other authors (1987). International Committee on Systematic Bacteriology. Report of the ad hoc committee on reconciliation of approaches to bacterial systematics. Int J Syst Bacteriol 37, 463-464.

Yoon, J.-H., Kim, H., Kim, S.-B., Kim, H.-J., Kim, W. Y., Lee, S. T., Goodfellow, M. \& Park, Y.-H. (1996). Identification of Saccharomonospora strains by the use of genomic DNA fragments and rRNA gene probes. Int J Syst Bacteriol 46, 502-505.

Yoon, J.-H., Lee, S. T. \& Park, Y.-H. (1998). Inter- and intraspecific phylogenetic analysis of the genus Nocardioides and related taxa based on 16S rRNA gene sequences. Int J Syst Bacteriol 48, 187-194.

Yoon, J.-H., Kim, I.-G., Shin, D.-Y., Kang, K. H. \& Park, Y.-H. (2003). Microbulbifer salipaludis sp. nov., a moderate halophile isolated from a Korean salt marsh. Int J Syst Evol Microbiol 53, 53-57.

Yoon, J.-H., Lee, M.-H., Kang, S.-J., Park, S.-Y. \& Oh, T.-K. (2006). Pedobacter sandarakinus sp. nov., isolated from soil. Int J Syst Evol Microbiol 56, 1273-1277. 